НАУКОВИЙ ВІСНИК

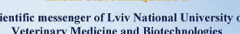

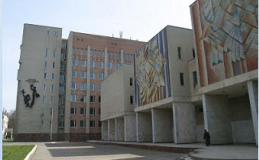

СЕРЯ: ВЕГЕРИНАРН НАУКИ

CRISS: VETERINARY SCIERG
Науковий вісник Аьвівського національного університету ветеринарної медицини та біотехнологій імені С.3. Гжицького. Серія: Ветеринарні науки

Scientific Messenger of Lviv National University of Veterinary Medicine and Biotechnologies. Series: Veterinary sciences

UDC 619:616.9-036.22; 619:616.9

\title{
Study of episootic situation at poultry farms for colibacteriosis and salmonellosis in Azerbaijan
}

\author{
S. B. Abbasov
}

Azerbaijan Veterinary Scientific Research Institute, Baku, Azerbaijan Republic

Article info

Received 05.07.2021

Received in revised form 09.08 .2021

Accepted 10.08.2021

Azerbaijan Scientific Research Veterinary Institute,

Kondelen Str., 8 P.O. Box: AZ1000, Baku, Azerbaijan Republic

Tel: + 38-050-330-21-90

E-mail:bav13@meta.ua

\begin{abstract}
Abbasov, S. B. (2021). Study of episootic situation at poultry farms for colibacteriosis and salmonellosis in Azerbaijan. Scientific Messenger of Lviv National University of Veterinary Medicine and Biotechnologies. Series: Veterinary sciences, 23(103), 56-59. doi: 10.32718/nvlvet10309

The article refers to the research work carried out in recent years at the poultry farms of the Khachmaz region of the Republic of Azerbaijan, the influence of opportunistic microbes on the activities of the farm. The role of opportunistic microbes in the occurrence of certain diseases with deficiencies in the process of feeding and raising of birds, and the microclimate in poultry farms is shown. During the bacteriological examination of breeding eggs by seasons there were revealed the presence of infection in the winter season with E. coli, Salmonella, Staphylococcus and Streptococcus - with each infection separately $13.0 \%$, in the spring season with E. coli, Salmonella, Staphylococcus - with each infection separately $20.0 \%$, in the autumn period with E. coli $27.0 \%$, Salmonella $40.0 \%$, Staphylococcus $13.0 \%$ and Streptococcus $13.0 \%$. In the course of bacteriological examination of dead embryos, the presence of infection in the winter period with E. coli $20.0 \%$, salmonella $30.0 \%$, staphylococcus $25.0 \%$ and streptococcus $25.0 \%$, in the spring season with E. coli $30.0 \%$, salmonella $40.0 \%$, staphylococcus $15.0 \%$ and streptococcus $15.0 \%$, in the autumn season with E. coli $45.0 \%$, salmonella $55.0 \%$ was revealed. In the autumn period, infection with staphylococci and streptococci was not detected. When studying as a whole, pseudomoniasis and mold fungi were not found.
\end{abstract}

Key words: chicken, incubation egg, laboratory examination, infection, contamination.

\section{Изучение эпизоотической ситуации на птицеводческих хозяйствах относительно колибактериоза и сальмонеллёза в Азербайджане}

\author{
С. Б. Аббасов
}

Азербайджанский научно-исследовательский ветеринарный институт, г. Баку, Азербайджанская Республика

В статье говорится о проводимых в последние годы научно-исследовательских работах на птицеводческих хозяйствах Хачмазского района Азербайджанской Республики, влиянии условно-патогенных микробов на деятельность хозяйства. Показывается роль условно-патогенных микробов в возникновении определенных заболевании при недостатках в процессе кормления и выращивания птии, микроклимата на птичеводческих хозяйствах. При бактериологическом исследовании племенных яии по сезонам было обнаружено наличие заражения в зимний период Э. коли, сальмонеллой, стафилококком и стрептококком - с каждой инфекиией по отдельности 13,0\%, в весенний период Э. коли, сальмонеллой, стафилококком- с каждой инфекиией по отдельности 20,0 \%, в осенний период с Э. коли 27,0 \%, сальмонеллой 40,0 \%, стафилококком 13,0 \% и стрептококком 13,0 \%. В ходе бактериологического исследования мертвых эмбрионов было выявлено наличие заражения в зимний период с Э. коли 20,0 \%, сальмонеллой 30,0 \%, стафилококком 25,0 \% и стрептококком 25,0\%, в весенний период с Э. коли 30,0\%, сальмонеллой 40,0 \%, стафилококком 15,0 \% и стрептококком 15,0\%, в осенний период с Э. коли 45,0 \%, сальмонеллой 55,0 \%. В осенний период заражение стафилококками и стрептококками обнаружено не было. При исследовании в целом псевдомоноз и плесневые грибы не обнаруже$H b l$ 
Ключевые слова: курица, инкубационное яйцо, лабораторное исследование, инфекция, заражение.

\section{Введение}

В начале 1990-х годов прошлого века реформы, осуществлялемые в аграрном секторе в нашей стране, включая в области животноводства и птицеводства привели к коренным изменениям в эпизоотологическом состоянии целого ряда инфекционных заболевании, а это делает необходимым коренным образом заново разработку мероприятий по лечению и профилактике, стратегию и тактику мер борьбы с рядом инфекционных заболевании сельскохозяйственных животных и птиц со стороны ветеринарной службы (Aliev et al., 2013; Mikailov et al., 2016; Vasilyeva, 2016; Godzhaev et al., 2018; Ivchenko et al., 2018).

Определенные успехи были достигнуты в изучении инфекционных заболеваний у домашних кур. Однако организация эффективных мер и методов борьбы с рядом заболеваний начинает приобретать все большее значение и при других новых заболеваниях. Колибактериоз и сальмонеллез также относятся к числу таких заболевании, которые часто отмечаются на птицеводческих хозяйствах и приводят к гибели птиц (Gorjunov, 1978; Zakomyrdin, 1981; Pourbakhsh et al., 1997; Ginns et al., 1998; Ablov et al., 2014; Glebenyuk et al., 2018).

В последние годы, в результате перехода птицеводства на фермерскую основу, эпизоотическая ситуация по многим инфекционным заболеваниям, в особенности по заболеваниям, вызываемыми патогенными и условно-патогенными микробами, значительно изменилась.

На фермерских птицеводческих хозяйствах, с одной стороны, в связи со скоплением птиц разных возрастов в большом количестве на ограниченном участке и регулярным их обновлением, недостатками в условиях кормления и содержания, еще большей чувствительностью плодовитых кроссов к стрессовым факторам и заболеваниям, с другой стороны, из-за прекращения развития полезной микрофлоры желудочно-кишечного тракта в связи с введением лекарственных препаратов цыплятам с первого дня ослабевает общее состояние и естественные защитные функции организма птицы.

Была поставлена цель - путем наших исследований определение наличия инфекционных заболеваниий на птицеводческих хозяйствах, причин их возникновения и распространения, источников инфекции, сезонности их распространения.

\section{Материалы и методы}

Исследования эпизоотической ситуации на условно-патогенные микробы проводились на фермерских птицеводческих хозяйствах Хачмазского района Азербайджанской Республики, а бактериологические исследования в отделе по заболеваниям птиц Азербайджанского научно-исследовательского ветеринарного института.
Во время исследования были проанализированы данные птицеводческих хозяйств Хачмазского района для выяснения эпизоотической ситуации. При этом было выяснено количество птиц в хозяйстве, условие содержания, состав корма, их процентное содержание в общем балансе, возраст птиц в цехах, источник комплектования родительских кур, хозяйственнотранспортные связи, ветеринарно-санитарные объекты, их состояние и реальная обработка в помещениях с чрезмерным падежом, птицы были проведены через клинический осмотр, были проанализированы динамика падежа, эффективность проведенных лечебно-профилактических мероприятии.

Исследование условно-патогенных микробов во всех сферах птицеводческого хозяйства; в инкубаторе, инкубационных яйцах, эмбрионах, в корме, в патологическом материале до и после дезинфекции цехов и инкубатора. С этой целью были обследованы общее количество микробов в МПА, помещенных в чашки Петри, микробов Э. коли в питательной среде Эндо, Сальмонелл в питательной среде с сульфидом Висмута, стрептококков со стафилококками в соляном МПА и плесневые грибы в питательной среде Сабуро. Микробы были инкубированы 48 часов при температуре $37{ }^{\circ} \mathrm{C}$, а плесневые грибы в течение 3-4-х дней при комнатной температуре. Изменение уровеня загрязненности микробами воздушной среды в птичниках в зависимости от условий содержания цыплят, времени года было изучено на основе патологических материалов, взятых с птицеводческих хозяйств Хачмазского района.

Пробы воздуха в птичниках были взяты в общепринятом порядке между 7-9 часов утра на высоте 25 см от пола в 3 местах. С этой целью были использованы вышеупомянутые питательные среды. Идентификация микробных культур, выделенных из воздуха помещений, проводилась в определенно принятом порядке.

Культуры были получены путем посева в вышеупомянутые питательные среды из костного мозга цыплят, желточного мешка эмбрионов, крови сердца и соскабливании, взятых из различных объектов, а для интерпретации были использованы питательные среды Эндо и сульфид Висмута.

Антигенная структура микробных культур, аналогичная группе сальмонелл, была определена с помощью набора монорецепторных $\mathrm{O}$ и $\mathrm{H}$ агглютинационных сывороток на основе соответствующих инструкции.

\section{Результаты и обсуждение}

Для выяснения распространения патогенных и условно-патогенных микробов в хозяйствах были проведены патологические вскрытия 15-20 тушек птиц с каждого хозяйства, в каждом сезоне были проведены бактериологические обследования культур (зима, весна, осень) 15 штук племенных яиц (всего 
45 штук), мертвых эмбрионов, в каждом сезоне (зима, весна, осень) 20 штук (всего 60 штук). В ходе обследования наряду с колибактериозом и сальмонеллезом были выявлены стафилококкоз и стрептококкоз.

Как показано в таблице 1, во время бактериологических исследовании, независимо от сезона, в 9 яйцах из 45 племенных яиц привезенных из хозяйств были обнаружены культуры Э. коли, в 11и сальмонелл, в 7-и стафилокков, в 4-х стрептококков, псевдомоноз и плесневые грибы обнаружены не были. В ходе бактериологического обследования племенных яиц было обнаружено заражение в зимний период с Э. коли, сальмонеллой, стафилококком и стрептококком - с каждой инфекцией по отдельности 13,0 \%, в весенний период с Э. коли, сальмонеллой, стафилококком - с каждой инфекцией по отдельности 20,0\%, в осенний период с Э. коли 27,0 \%, а с сальмонеллой 40,0 \%, стафилококком 13,0 \% и стрептококком 13,0 \% (таблица 1).

\section{Таблица 1}

Бактериологическое обследование племенных яиц

\begin{tabular}{|c|c|c|c|c|c|c|c|c|c|c|c|c|c|c|}
\hline \multirow{2}{*}{$\begin{array}{c}\text { Времена } \\
\text { года }\end{array}$} & \multirow{2}{*}{$\begin{array}{l}\text { Количе- } \\
\text { ство яиц }\end{array}$} & \multirow{2}{*}{$\begin{array}{c}\text { Зара- } \\
\text { женные } \\
\text { яйца }\end{array}$} & \multicolumn{2}{|c|}{ Э. коли } & \multicolumn{2}{|c|}{ Сальмонелла } & \multicolumn{2}{|c|}{ Стафилококк } & \multicolumn{2}{|c|}{ Стрептококк } & \multicolumn{2}{|c|}{ Псевдомоноз } & \multicolumn{2}{|c|}{$\begin{array}{c}\text { Плесневые } \\
\text { грибы }\end{array}$} \\
\hline & & & кол. & $\%$ & кол. & $\%$ & кол. & $\%$ & кол. & $\%$ & кол. & $\%$ & кол. & $\%$ \\
\hline Зима & 15 & 8 & 2 & 13,0 & 2 & 13,0 & 2 & 13,0 & 2 & 13,0 & - & - & - & - \\
\hline Весна & 15 & 9 & 3 & 20,0 & 3 & 20,0 & 3 & 20,0 & - & - & - & - & - & - \\
\hline Осень & 15 & 14 & 4 & 27,0 & 6 & 40,0 & 2 & 13,0 & 2 & 13,0 & - & - & - & - \\
\hline
\end{tabular}

Как показано в таблице 2, во время бактериологических исследований мертвых эмбрионов, у 19 в целом из 60 штук привезенных из птицеводческих хозяйств были обнаружены Э.коли у 25 , сальмонеллы у 8, стафилококки у 8, стрептокок$\kappa и$, псевдомоноз и плесневые грибы обнаружены не были. Во время бактериологического обследования мертвых эмбрионов было выявлено наличие заражения в зимний период с Э. коли 20,0 \%,

\section{Таблица 2}

Бактериологическое обследование мертвых эмбрионов

\begin{tabular}{|c|c|c|c|c|c|c|c|c|c|c|c|c|c|c|}
\hline \multirow{2}{*}{$\begin{array}{l}\text { Времена } \\
\text { года }\end{array}$} & \multirow{2}{*}{$\begin{array}{c}\text { Количество } \\
\text { эмбрионов }\end{array}$} & \multirow{2}{*}{$\begin{array}{c}\text { Инфици- } \\
\text { рованные } \\
\text { яйца }\end{array}$} & \multicolumn{2}{|c|}{ Э. коли } & \multicolumn{2}{|c|}{ Сальмонелла } & \multicolumn{2}{|c|}{ Стафилококк } & \multicolumn{2}{|c|}{ Стрептококк } & \multicolumn{2}{|c|}{ Псевдомоноз } & \multicolumn{2}{|c|}{$\begin{array}{c}\text { Плесневые } \\
\text { грибы }\end{array}$} \\
\hline & & & кол. & $\%$ & кол. & $\%$ & кол. & $\%$ & кол. & $\%$ & кол. & $\%$ & кол. & $\%$ \\
\hline Зима & 20 & 20 & 4 & 20,0 & 6 & 30,0 & 5 & 25,0 & 5 & 25,0 & - & - & - & - \\
\hline Весна & 20 & 20 & 6 & 30,0 & 8 & 40,0 & 3 & 15,0 & 3 & 15,0 & - & - & - & - \\
\hline Осень & 20 & 20 & 9 & 45,0 & 11 & 55,0 & - & - & - & - & - & - & - & - \\
\hline
\end{tabular}

Бактериологическое исследование пробы воздуха инкубатора. Для выяснения роли инкубатория и времени года в распространении указанных условно-патогенных микробов были исследованы 15 проб воздуха. При исследовании уровня загрязненности микробами воздуха птичников были выявлены нижеследующие инфекции: Э. коли, Сальмонелла, Стафилококк, Стрептококк, Псевдомоноз, Плесневые грибы.

Таким образом, в опытах было выявлено, что роль инкубаторов в распространении этих условнопатогенных микробов велика.

Во время бактериологических исследовании кормов кишечные палочки были обнаружены в 10 видах комбинированных кормов. Поскольку пшеница является основой комбикорма, который дается птицам, наряду с микробами Э. коли также была выявлена загрязненность плесневыми грибами.

Инфекционные заболевания наносят большой урон с экономической точки зрения хозяйствам, сальмонеллой 30,0 \%, стафилококком 25,0% и стрептококком 25,0 \%, в весенний период с Э. коли 30,0 \%, сальмонеллой 40,0 \%, стафилококком 15,0\% и стрептококком 15,0\%, в осенний период с Э. коли $45,0 \%$, сальмонеллой 55,0 \%. В осенний сезон заражение стафилококком и стрептококком обнаружены не были. Во время обследования псевдомоноз и плесневые грибы не были обнаружены (таблица 2). являющимся объектами исследовании. Основным способ искореннения этих заболевании в хозяйствах это полное стерильное состояние племенных заводов, в полной и строгой форме выполнение ветеринарносанитарных мероприятий в инкубаторах, а также обязательное функционирование птицеводческих хозяйств в закрытых условиях. Наряду с этим для повышения резистентности птиц к заболеванию необходимо использовать сбалансированный корм, обогащенный витаминами и микроэлементами.

\section{Заключение}

1. Во время бактериологического исследования племенных яиц было обнаружено наличие заражения в зимний период Э. коли, сальмонеллой, стафилококком и стрептококком - с каждой инфекцией по отдельности 13,0 \%, в весенний период Э. коли, сальмонеллой, стафилококком - с каждой инфекцией по отдельности 20,0 \%, в осенний период с 
Э. коли 27,0 \%, сальмонеллой 40,0 \%, стафилококком $13,0 \%$ и стрептококком $13,0 \%$.

2. Во время бактериологического исследования мертвых эмбрионов было выявлено наличие заражения в зимний период с Э. коли 20,0\%, сальмонеллой 30,0 \%, стафилококком 25,0 \% и стрептококком 25,0\%, в весенний период с Э. коли $30,0 \%$, сальмонеллой 40,0 \%, стафилококком 15,0\% и стрептококком 15,0\%, в осенний период с Э. коли 45,0 \%, сальмонеллой 55,0 \%. В осеннее время года заражение стафилококком и стрептококком обнаружено не было. В ходе исследования псевдомоноз и плесневые грибы не были выявлены.

\section{References}

Ablov, A. M., Batomunkuev, A.S., Angonova, E.V., \& Mel'cov, I. V. (2014). Primenenie staticheskih metodov pri analize jepizooticheskoj situacii po infekcionnym boleznjam zhivotnyh i ptic: metodicheskie rekomendacii. Irkutsk: IrGSHA (in Russian).

Aliev, Je. A., Azimov, I. M., Valiev, U. M., \& Safi, N. V. (2013). Jepizootologija i infekcionnye zabolevanija. Baku (in Russian).

Ginns, C. A., Browning, G. F., Benham, M. L., \& Whithear, K. G. (1998). Development and application of aerosol challenge method for reproduction of avian colibacil-losis. Avian Pathol., 27(5), 505-511. doi: 10.1080/03079459808419375.

Glebenyuk, V. V., Borovik, I. V., Kuchuk, T. V., \& Litvinenko, O. O. (2018). Etiological structure of bacteriosis of animals in the Dnipropetrovsk region for
2014-2016. Scientific Messenger of Lviv National University of Veterinary Medicine and Biotechnologies, 20(83), 260-263. doi: 10.15421/nvlvet8351.

Godzhaev, A., Abbasov, A., Gusejnov, A., \& Mamedov, Dzh. (2018). Uslovija soderzhanija i vyrashhivanija brojlernyh ptic Ross. Baku. "Ieroglif', 12-24 (in Russian).

Gorjunov, H. A. (1978). Domashnjaja ptica v priusadebnom hozjajstve Moskva, Rossel'hozizdat, 16-21.

Ivchenko, V., Papchenko, I., Levkivska, N., \& Levkivskyy, D. (2018). Colibacillosis in Chickens and Prophylaxis Methods. Scientific Messenger of LNU of Veterinary Medicine and Biotechnologies. Series: Veterinary Sciences, 20(88), 89-93. doi: 10.32718/nvlvet8816.

Mikailov, M. S., Askerov, A. R., Gasanaliev, N. H., \& Gasanova, M. S. (2016). Izuchenie jepizooticheskoj situacii kolibakterioza i sal'monelleza ptic. Sbornik Nauchnyh Trudov Veterinarnogo NauchnoIssledovatel'skogo Instituta, 34, 56-59 (in Russian).

Pourbakhsh, S. A., Boulianne, M., Maztineau-Doize, B., \& Fairbrother, J. M. (1997). Virulence mechanisms of avian fimbriated Escherichia coli in experimentally inoculated chikens. Vet Mikrobiol, 58(2-4), 195-213. https://www.ncbi.nlm.nih.gov/pubmed/9453131.

Vasilyeva, T. (2016). The monitoring of epizootic situation of colibacteriosis in ukraine during 2004 2015. Scientific Messenger of LNU of Veterinary Medicine and Biotechnologies. Series: Veterinary Sciences, 18(2(66), 30-34. doi: 10.15421/nvlvet6607.

Zakomyrdin, A. A. (1981). Veterinarno-sanitarnye meroprijatija v promyshlennom pticevodstve. Moskva, "Kolos", 23-33 (in Russian). 